\title{
Currículo, cultura e crueldade: para compor uma ética com Antonin Artaud e o teatro
}

Thiago Ranniery Moreira de Oliveira*

Marlucy Alves Paraíso**

\section{Resumo}

Este artigo busca nas linhas de força de Antonin Artaud, do Teatro da Crueldade e da Filosofia da Diferença de Gilles Deleuze elementos para compor uma ética da crueldade curricular. Desenvolve-se, assim, o argumento de que a crueldade das formas de vida e a crueldade das forças de uma vida permitem alimentar exigência de uma ética da crueldade curricular. Expóe-se, desse modo, a dimensão ética e cultural da crueldade a partir do duplo formas/forças posto em jogo no Teatro da Crueldade. Extrai-se, portanto, uma ética da crueldade curricular que funciona a partir de dois movimentos: dar conta dos autoengendramentos das formas de vida em um currículo e pensar os movimentos fecundos que possibilitam a permanente invenção de formas de viver.

Palavras-chave: Teorias de Currículo. Conteúdos culturais do currículo. Filosofia da Educação.

\footnotetext{
* Mestre em Educação pela Universidade Federal de Minas Gerais (UFMG), e Doutorando em Educação na Universidade do Estado do Rio de Janeiro (UERJ).

** Doutora em Educação pela Universidade Federal do Rio de Janeiro (UFRJ) e PhD em Educaçáo pela Universidade de Valencia, Espanha. Professora Associada da Faculdade de Educaçáo e do Programa de Pós-graduação em Educação da Universidade Federal de Minas Gerais (UFMG).
} 
A crueldade aflige, dilacera, despedaça. A crueldade tortura, esfrangalha, eviscera. A crueldade calcina, esquarteja, esmigalha. A crueldade destrói, aniquila, devasta. A crueldade nos chega por muitos caminhos. Conhecemos a crueldade de muitas formas. Ora, uma experiência imediata. Ora, um tema de obras literárias, cinematográficas ou pictóricas. Quase sempre, uma manchete de jornal ${ }^{1}$. Às vezes, um conflito filosófico ${ }^{2}$. Se houver espaço, um problema acadêmico. "O terrível século XX", nas palavras de Hobsbawn (1995, p. 14), foi o século mais assassino de que temos notícias tanto em registro, escala e frequência das guerras que o preencheram, como também pelo volume único das catástrofes que produziu desde as maiores fomes da história ao genocídio sistemático. A crueldade tornou-se um nome comum para muitos tipos de experiência que a nossa cultura produziu, costumeiramente associadas à carnificina, ao canibalismo, à violência e ao terror humano de todo o dia.

Se considerarmos, a título de exemplo, essa imagem de pensamento recorrente sobre a crueldade que muitos dos nossos discursos têm se dedicado a compreender, é perceptível como a crueldade é mencionada principalmente para mostrar o quanto nossas sociedades se empenham em controlá-la, codificá-la, ritualizá-la, em suma, mostrar que tendemos ou precisamos reduzi-la, quando não a aboli-la. Evoca-se a crueldade, mas, sobretudo, para mostrar o horror que ela nos inspira, para estabelecer que somos, no final das contas, sociedades contra a crueldade; ela não pertence ao funcionamento "normal" das sociedades. Contudo, por razóes que não unicamente materiais, não podemos expor aqui os problemas náo resolvidos que essa imagem de pensamento da crueldade deixa aos currículos na medida em que a crueldade só figura no horizonte imaginativo sob o signo do diálogo entre o discurso crítico e o discurso clínico. Certamente, interrogar-se sobre a unidade problemática desses dois discursos também foge ao escopo deste artigo. Sentimos apenas que um lugar-comum nos inquietou diante do trabalho reservado à crueldade no e dos currículos: náo se deve pensar que é necessário, seja por precauçáo moral, seja por motivaçáo estética, proteger a existência curricular e a singularidade de suas vidas contra a crueldade.

Não será surpreendente, então, constatar, no campo do currículo, a quase ausência de uma reflexão geral sobre a violência em sua forma ao mesmo tempo mais brutal e mais coletiva, mais pura e mais social: a violência material dos discursos fundantes (BUTLER, 1998), a violência dos poderes instituídos (MAFESSOLI, 1981), a violência da perda irreparável de uma origem que aponta para a impossibilidade de um sentido eterno e imutável e a necessidade 
de viver de significaçōes fugazes, ou aquilo que doravante, como aprendemos com Antonin Artaud (2006), chamaremos de crueldade. Um nome para a tradução portuguesa de cruor, de onde deriva crudelis, designação para a carne escorchada e ensanguentada, assim como crudus, que por sua vez, designa cru, não digerido, indigesto (ROSSET, 2002). Mas também, como sugere Dale (2002), crueldade é um nome para tudo aquilo que abandona o campo claro e ordenado da percepção diária, tudo que inverte as aparências e introduz a dúvida, tudo que provoca confusão, que perturba a relação entre as coisas, dando a este pensamento agitado um aspecto ainda maior de verdade e violência - de crueza, indigestão e de inominável; oferecendo uma brecha de vida que nos coloca em contato com certos estados mais agudos de expressão sensível.

Quando se tem ensaiado, no território curricular, esse "outro teatro da crueldade" (GALENO, 2005, p. 161), bem distante da imagética radical do Teatro da Crueldade de Artaud, mais próximo da violência degradante do corpo físico, a crueldade é sacrificada nos jogo dos conceitos curriculares. Essa espécie de silêncio sacrificial que se instaura no território curricular parece derivar náo só de uma marginalidade das imagens de pensamento da crueldade, mas também de uma imagem náo pensável que preocupa um currículo tanto mais quanto é delegada a problemática a outros territórios disciplinares. Seja, contudo, sob o signo da violência física ou moral, da agressão ou da patologia, a crueldade acaba por entrar no jogo conceitual para repetir o silêncio de um currículo que parece provir de uma impossibilidade de inscrever a crueldade em seu pensamento. $\mathrm{O}$ escape à captação conceitual pelos currículos parece poder pôr em jogo a experiência curricular como tal, cujo estatuto permanece enigmático, a saber: seu princípio de crueldade ${ }^{3}$, nos termos de Clement Rosset (2002) - que o currículo, um currículo, qualquer currículo torna-se um exercício de crueldade.

Estamos, de início, diante de um paradoxo que o presente artigo pretende explorar: a crueldade como elemento vivo dos discursos que constituem a vida dos currículos e a crueldade como potenciaçáo do estar no mundo em busca de sondar elementos de virtualidade na experiência curricular. Entre essas duas teses aparecem dois temas caros ao território curricular: cultura e ética. Conectar crueldade, ética e cultura em um currículo é o objetivo a que este artigo se propõe. Nosso desafio é buscar nas linhas-força de Antonin Artaud, do Teatro da Crueldade e da filosofia da diferença de Gilles Deleuze elementos para tramar uma composição entre currículo e crueldade. Caminhamos, portanto, a partir 
de um argumento: a crueldade das formas de vida e a crueldade das forças de uma vida permitem alimentar exigência de uma ética da crueldade curricular. Usamos Artaud e o Teatro da Crueldade como um intercessor para problematizar o exercício de crueldade de um currículo em seu matrimônio com a cultura. Exploramos, aqui, por um lado, o exercício cruel de fabricação de formas de vida em um currículo e, por outro, o exercício de crueldade como aquele pelo qual as forças de uma vida tocam as formas de vida em um currículo a partir da qual podemos extrair um exercício ético.

\section{O duplo da crueldade: entre as forças e as formas}

Há anos no teatro estamos lendo Antonin Artaud, explicando, comentando, buscando compreendê-lo, tentando manter viva uma obra que quis "acabar com as obras-primas" (ARTAUD, 1983) e pensar o teatro em alguma das direçôes que ele apontou ${ }^{4}$. Porém, há anos as imagens difusas de Artaud e do Teatro da Crueldade têm construído uma espécie de muro estéril em torno de seus textos, criando sobre a crueldade uma imagem de pensamento largamente confundida com sangue, trucidamento e perversão. É o próprio Artaud (2006, p. 177) que alerta sobre o uso do termo: "não se trata, nessa crueldade, nem de sadismo, nem de sangue [...]. A palavra crueldade deve ser considerada num sentido amplo [...] e não no sentido que geralmente lhe é atribuído". Artaud $(2006,119)$ continua, "uso crueldade no sentido de vida, no sentido gnóstico de turbilhão de vida que devora as trevas, no sentido da dor fora de cuja necessidade inelutável a vida não consegue se manter". A crueldade é a própria vida, outro nome para vida, na medida em que, toda força, a cada instante, distende a vida até o limite constituindo formas - "disse crueldade como teria dito vida" (ARTAUD, 1978, p. 137).

Se for útil fazer certo mapeamento para que percebamos os meandros da "cruel razão poética" (BLANCHOT, 2001, p. 43) de Artaud, no que concernem as imagens de seu pensamento sobre a crueldade, não quer dizer que seja possível lhe dar um sentido único e permanente, inserir-lhe uma racionalidade externa e iluminatória. Nem sequer podemos nos remeter a possibilidade de um núcleo estável da crueldade na obra de Artaud ${ }^{5}$. Um estudo, ainda que sem profundidade, denota logo que ela ultrapassa muito a ideia de teatro tradicional que nós temos (VIRMAUX, 1978). Contudo, a crueldade excede largamente uma reflexão puramente teatrológica, suas linhas de pensamento vão além de se 
imprimirem na arte chamada "teatro". Espalham-se por toda a cultura ocidental, compóem "um sistema de críticas abalando o todo da história do Ocidente mais do que um tratado de prática teatral" (DERRIDA, 1971, p. 153). A crueldade é da ordem da cultura náo porque se apresenta nas formas, modelos ou práticas teatrais; ela compóe essa ordem em um sentido absoluto e radical.

Artaud reconhece mesmo uma linha da crueldade que se conecta com a tortura e violência física, tal como nós a conhecemos, ao denunciar, por exemplo, o genocídio sistemático do regime nazista (Carta a Sônia Mossié) ou as situaçōes pelas quais passava nos manicômios (Carta aos chefes de manicômios). Em seus projetos de encenação, da tragédia Os Cenci até Tiestes de Sêneca e MacBeth de Shakespeare, ocorrem com frequência mortes, suplícios e até certo sadismo na exibição deles. A exposição nua e crua desse material, contudo, não é gratuita. Não há um interesse de utilizar a imagem física da crueldade para uma representação fiel e clara da "baixeza humana". Ainda que haja um efeito quando rostos e corpos de atores se contorcem, gritam, atacam a moralidade do público, o território cênico não se altera de maneira fundamental pela mera exibição da crueldade física. "Não se trata mais, então, apenas do espaço real que o palco nos apresenta, mas de um outro espaço" (BLANCHOT, 2001, p. 43). A vivência e a exposição do sangue, da morte, do sadismo e seus afins, permite que vivamos uma "crueldade muito mais terrível e necessária que as coisas podem exercer contra nós” (ARTAUD, 1978, p. 95).

A crueldade física é a expressão comum de uma crueldade da existência humana, uma crueldade da vida, uma crueldade de se estar vivo. "Eu sofro terrivelmente da vida. Não há nenhum estado que eu possa atingir" (ARTAUD, 1976, p. 20). O teatro torna-se, assim, a possibilidade da exposição física da crueldade trazer à tona o testamento de nossa existência. "Sei que estou enfermo e que sofro muito, não tanto das más condiçôes físicas, mas de outros males que são quase os mesmos que me torturam aqui e que, em todo caso, tem a mesma causa" (ARTAUD, 1977, p. 21). O espaço cênico é aquele capaz de fazer das matérias que tomamos por estatutárias da vida, exercício de criação poética, potencializando a existência. Estamos, aqui, diante da efetiva realização do Teatro da Crueldade. "Atitudes temíveis e que se tomam por inumanas são mesmo, talvez, o solo fecundo de onde somente pode surgir alguma humanidade, tanto sob a forma de emoçóes, como de açóes e obras" (NIETZSCHE, 1983, p. 192). A possibilidade, enfim, de viver a crueldade da vida em todas as suas formas para restituir ao homem a liberdade criadora instauradora das forças 
do mundo (DUMOULIÉ, 1996). A crueldade é expressão dessa tensão entre as forças do mundo e as formas de uma vida. Nome para o conflito primordial entre forças e formas que dilaceram o homem a cada minuto e que o faz brotar desse dilaceramento entre a força vital e as formas do vivo, entre a pulsão que nos atravessa e o corpo que temos que construir. "Há a verdade que é terrivelmente cruel. É tudo” (ARTAUD, 1967, p. 195).

O homem, esse artifício fabricado na cultura que um currículo se empenha em produzir, existe, portanto, entre duas coaçôes: as que o matam e as que o fazem viver. De um lado, a crueldade é máquina coercitiva, porém, formadora dos princípios da vida, dos signos que se inscrevem no corpo ou das categorias que estruturam a sensibilidade. Uma crueldade que é de ser quem se é - uma crueldade que é das coerções do Ser como princípio, forma e lugar da existência (REY, 2002). De outro, é a violência das forças que jorra como um jato, impulsionando a vida para o movimento, permitindo que outras forças entrem na composição da existência para alcançarmos "uma espécie de vida liberada, que ponha de lado a individualidade humana e na qual o homem não passa de um reflexo" (ARTAUD, 1978, p. 139). Solicitar a crueldade é estarmos diante da condição daquilo que um currículo nos separa: a própria vida. Possibilita a chance de acessar, a todo instante, um reservatório de novos possíveis. "Sinto que um outro homem nasce" (ARTAUD, 1967, p. 176). O projeto do Teatro da Crueldade de Artaud era a reconstruçáo da existência humana. E não é este um dos sonhos de muitos de nós em um currículo?

Já ressoa entre as linhas do território curricular um grito ou um sopro para rasgar as peles e os corpos de um currículo, para trazer à tona que não estamos ou não temos porque permanecer fechados em nós mesmos (CORAZZA, 2002, 2010; TADEU; PARAÍSO, 2010a, 2010b, 2010c). Poderia mesmo existir um currículo que abdique das formas em nome de mobilizar forças? Pôr a crueldade em cena para se deliciar na pele da vida com seus desdobramentos e deslizes, com as "novas revelações do ser" (ARTAUD, 1967, p. 43)? Se a crueldade permeia um currículo por ser um constituinte de formas - formas de ser, de estar, de viver no mundo, junto ou separado, que um currículo não cessa de fabricar e encerrar em si mesmas -, ela também pode oferecer a potência de uma vida ao nos convidar a um exercício de resistência diante do atrofiamento dos sentidos de um currículo. Uma crueldade que funciona em um currículo a partir de dois movimentos: dar conta tanto dos autoengendramentos das formas de vida em um currículo, bem como dos movimentos fecundos e virtuais 
que possibilitam a permanente invenção de formas de viver. Concorrência e enfrentamento, portanto, entre dois regimes, duas dimensóes ou dois tempos da crueldade que pressupóe tanto uma ideia negativa como uma problematização positiva da cultura, isto é, onde uma ética aparece diretamente como correlata de uma criação.

\section{Das formas de vida: um currículo e a invenção da cultura}

Currículos constituem formas de vidas: formas de vida generificadas (CUNHA, 2011; REIS, 2011; CARVALHAR, 2009; PARAÍ́SO, 2010a, 2010b), formas de vidas infantis (SILVA, 2010), formas de vida discentes e docentes (FREITAS, 2008), formas de vidas juvenis (SALES, 2010). Em um currículo, vivemos de alguma forma. Entramos ou saímos de forma. Estamos ou não em forma. "Formas são odes do espírito humano a facilidade" (CORAZZA, 2010, p. 81). Pelas formas, somos informados. Nossos conceitos sintetizam formas. Tateamos para reconhecer formas. É mesmo possível produzir uma enciclopédia, um conjunto de inventários só com formas de vida que um currículo produz. O que é, porém, uma forma de vida de um currículo? De onde surgem as formas de vida? No que elas são tão desejáveis? Como é possível seu surgimento na cultura e em um currículo? Que funçáo desempenha uma forma de vida? Será isto viver? Viver é viver uma forma?

Conhecemos bem no território curricular a fórmula das formas de vidas como cultura ${ }^{6}$ (WILLIAMS, 2008) posta em cena pelos Estudos Culturais ${ }^{7}$, que sempre estiveram às voltas com as questóes das formas através das quais nos sustentamos subjetivamente (JOHNSON, 2006). Tendo em vista a centralidade da cultura na contemporaneidade ${ }^{8}$, muitas das teorizaçóes curriculares "migraram para o explosivo avanço dos Estudos Culturais" (PINAR, 2002, p. 14) e arrastaram consigo o fato de que um currículo não pode se definir formal ou metodologicamente, mas que está obrigado a se autoposicionar sobre o horizonte material de uma cultura dada? . Afinal, o campo cultural está indissociavelmente ligado à vida, é ela que tem que dar o testemunho de sua qualidade (DELEUZE, 1976). Tomar, a partir de então, a relação entre formas de vida e crueldade é pode dizer que esse posicionamento de um currículo não pode ter a forma de subordinação, do diálogo ou do consenso, porque o que está por detrás é uma luta sem tréguas entre as forças do pensamento. 
Os pressupostos da cultura erguem-se como uma espécie de campo de batalha ou teatro de operaçóes, no qual toda forma de vida que um currículo cria e sustenta aparece como "um composto de relaçôes de forças" (DELEUZE, 1988, p. 167), produto de um jogo múltiplo e muito concreto das forças de um currículo que dão forma a vida. Onde há vida, há combate de força contra força. Há forças agindo sobre outras e sendo levadas a agir por elas, há crueldade de agir. Há força com vontade de potência que quer comandar outra vontade e ter sua potência intensificada ${ }^{10}$. "Não se faz nada, não diz nada, mas sofre-se, desesperase e combate-se, sim, creio que em realidade combate-se" (ARTAUD, 1974, p. 236). Toda forma de vida é erguida sob essa incessante luta de forças que compõe um currículo. De outro modo, a formação de uma vida continuaria um mistério improvável ou um milagre se não se concedesse à ação e ao combate das forças entre si, no qual uma força submete outra força a própria unidade que ela supóe ter (DELEUZE, 1991). Um currículo está sempre em relação com as forças da vida das quais ele se apropria, territorializando-as em formas de existência. Faz da vida dos seres uma forma ou mesmo muitas formas de vida quando lhes oferecem aparelhos de saberes, narrativas, histórias, arquiteturas, conceitos, a partir das quais podemos nos proclamar como sujeitos de nós mesmos.

Só que uma forma de vida de um currículo é apenas uma atualização muito especial entre forças num campo de multiplicidade que o povoa. "Não importa quão habitual, repetitiva e socialmente compulsória, ela retêm sempre o caráter de uma possibilidade" (AGAMBEM, 2000, p. 74). Ela é apenas um modo muito particular de se exercer a vida, um dos modos pelo qual as forças da vida entram em relaçáo. A questâo é que os currículos como conhecemos institucionalizam essa guerra de forças dentro de si. Aproximam-se de certas descriçóes de Artaud (1993, p. 32): "esta cidade de cavernas e muros que projecta arcos cheios e cavos como pontes no abismo absoluto". Lutam para manter a coerência das formas, o "andar interior de cima" (DELEUZE, 1991, p. 54) que se erguem acima da textura infinitamente cavernosa das forças e expulsar toda força que for estranha a elas. Fazem das formas um entorpecimento do jorro incontrolável das forças, em uma esperança desesperada para que uma unidade se dê em um plano superior. Eis uma espécie de expressão de protesto contra o incontrolável campo de forças, atracadouro que oferece segurança ante o oceano voraz da vida. Na descrição de Artaud (1976, p. 57):

[...] a carne não toca mais na vida / esta língua que não chega a ultrapassar sua casca/ esta voz que não passa mais 
pelas vias do som/ esta mão que esqueceu mais que o gesto e tomar/ que não chega a determinar o espaço onde ela se realizará sua preensão / este cérebro enfim onde a concepção não se determina mais em suas linhas / tudo isso que faz minha múmia de carne fresca / dá adeus do vazio onde a necessidade do ser não se colocou mais.

Poder falar em crueldade no pensamento de currículo é para poder expressar essa separação brutal entre formas de vida e as forças de uma vida que um currículo produz na cultura. "Uma ruptura entre as coisas e as palavras" (ARTAUD, 1978, p. 9). A criação e existência de uma forma de vida tornam-se, deste modo, um exercício de crueldade. "É com crueldade que se coagulam as coisas, que se formam os planos do criado" (ARTAUD, 2006, p. 92). É com crueldade que um currículo cristaliza o jogo das forças em formas de vida na cultura. $\mathrm{O}$ ato de escrever a vida, de espalhar a tinta na cultura, está meteoricamente vinculado à crueldade (LINS, 2003). Uma vida separada das forças que a produziu como forma e a faz passar: eis a condiçáo essencial para o nascimento da cultura (NIETZSCHE, 2007a). A invenção da cultura, o modo como nos tornamos seres dotados e conscientes de cultura não se faz sem uma dose de crueldade e adestramento. "A cultura é adestramento e seleção" (DELEUZE, 1976, p. 62), age, nomeia, dirige as forças em formas de vida. Obrigada a encontrar explicaçôes racionais para práticas cujas razóes são desconhecidas, a consciência da cultura não é uma mera racionalização, mas uma quase-tradição consistente com os saberes, narrativas e interesses da sociedade (WAGNER, 2010). É um modo propriamente humano de se defrontar com tudo aquilo que o ultrapassa, uma atividade de inflexão das forças, através da qual se cria uma forma de vida e encerra dentro de si nada mais que forças, com suas partículas desaceleradas segundo um ritmo próprio, seja ele dos tambores africanos ou do electro music na boate, e em uma velocidade específica, onde nos tornamos mestres de nossa velocidade.

A crueldade de um currículo é da ordem da cultura, é de como da fabricação de formas de uma vida extraímos uma cultura, de como o exercício de constituir formas de existir torna-se um exercício de crueldade, ao ponto que é possível afirmar que a crueldade é "um dos mais antigos e indeléveis substratos da cultura" (NIETZSCHE, 2006, p. 38). Uma cultura, assim, não se faz separável dos meios atrozes que servem para adestrar as forças da vida em formas de existência. O alimento da cultura é uma vontade de crueldade 
(ALMEIDA, 2008). Campo de tortura, seu traçado marca uma territorialidade, uma sensação de pertença, como uma tatuagem que é talhada na pele a ferro e fogo. No depoimento de Artaud (1979, p. 76):

Eu, uma vez marcado, torna-se cidadáo, habitante, cultivado, sim, cultivado, lavrado: eu tenho uma valeta traçada no meu corpo que repete a lei, a fórmula inexorável 'tu deves'. Passei pela máquina cultural horripilante trituradora de singulares. Estou marcado como todos os outros.

Afinal, a história já tem mesmo nos apontado toda a violência da cultura como sua propriedade legítima (DELEUZE, 1976; 2008). De fato, o quanto de crueldade não foi preciso para fabricar essa forma homem atual (NIETZSCHE, 2009)? O quão de técnicas cruéis não foi disposto para docilizar esse corpo de forças na forma-homem (FOUCAULT, 1999)? O quão de vigilância punitiva não fui usado para dar forma ao corpo do humano (LUENGO, 2010)? E mesmo que estejamos falando em tecnologias dóceis (FOUCAULT, 1999), em tecnologia do afeto nos currículos (PARAÍSO, 2010a; 2010b) ou em dispositivo da plenitude pedagógica (ALVES, 2009), ainda estamos falando de uma localização fabricada e marcada das forças em formas de vida supostamente fechadas em si mesmas, localizáveis, nomeáveis e reconhecíveis nos currículos.

O quão, de fato, um currículo não é cruel ao propagar a uma forma de vida como a única possível? O quanto não é um currículo cruel ao constituir formas de vida ou pelo menos se deter exclusivamente nesse exercício? Um currículo não tem sido mesmo terreno privilegiado da metafísica, solo fértil para todo tipo de essencialismos, boa vontade e bons sentimentos do sujeito humanista (TADEU; CORAZZA, 2003)? Como expressão da cultura, é também uma prática de seleção e adestramento. Seus procedimentos encurralam a multiplicidade sedenta e faminta das forças em uma forma de vida humana. Não é ao acaso que uma aceitação da crueldade como produção homem para existir enquanto forma de vida humana parece nos colocar diante dos nossos medos de perder a própria ideia de natureza humana. Currículos tornam-se só mais um meio de organizar, conservar e propagar uma forma de vida como a Vida, enclausurada, amordaçada, atada a pregos na forma. Um currículo é, pois, resultado dessa mortificação primeira que aprisiona e entorpece. Eis o desespero de Artaud (1978, p. 206): "Como alguém que dorme e cambaleia, 
perdido/ nas trevas de um sonho atroz/ que a própria morte,/ hesita antes de abrir os olhos/ pois sabe que aceitar viver/ é renunciar a desesperar-se". Um currículo, assim, trabalha permanentemente na expulsão da crueldade dos seus sistemas de pensamento, na tentativa de bani-la para o exterior do homem à custa de tornar a crueldade seu próprio princípio de existência.

Posta e dita, assim, a crueldade é mesmo um fardo. Talvez seja o momento de livrar-se do já dado e pensado em um currículo para liberar a potência da crueldade em um currículo. Experimentar o convite que Artaud (1978, p. 206) propôs a si: "assim, como uma alma marcada/ pelas almas que me levaram a vida/ eu relanço para o deus que me fez/ essa alma como um incêndio/ que o cure de criar". Se uma vontade compulsória por composição de formas tomou de assalto a vida do currículo, se um currículo é expressão dessa vontade compulsória de formas de vida quem tem como corolário a vontade de controle moderna, o signo da crueldade também não deixa de indicar que há um mundo de forças que pulsa fora de nós e que as formas de vida acabam por recusar. Ali "onde se malham as forças" (ARTAUD, 1993, p. 31), ali, onde "a sombra do eclipse faz uma parede de ziguezagues da elevada alvenaria do céu" (ARTAUD, 1993, p. 31), a crueldade permite-nos invocar uma ética da crueldade curricular na qual entram em jogo as múltiplas forças que compóem uma forma de vida. Lei cósmica da crueldade na qual um currículo, ao se afirmar, afirma também sua incineração e ainda uma consciência aplicada desse exercício.

\section{Das forças de uma vida: por uma ética da crueldade curricular}

Não haveria um currículo se a crueldade fosse para nós, simplesmente, uma coisa expurgável, que ele simplesmente a afastasse ou ela se eclipsasse irremediavelmente. A crueldade atravessa o mundo de um currículo, aterroriza seu pensamento. Seja como for, fascina mesmo quando mortifica, provoca, mesmo quando nos assusta. A crueldade tem seu charme discreto (REY, 2002), sua doçura e delicadeza, "sua morbidezza" (HEGEL, 2004, p. 65), sua embriaguez inebriante, até uma alegria inventiva e insaciável. O casal Currículo e Crueldade permite perceber a lógica da repetição e da multiplicidade das máquinas esterilizantes que soçobram a síncope conceitual curricular, parada, paralisante, por considerar que estes sáo momentos decisivos, nos quais o pensamento curricular descobre tanto a sua falha como seu campo 
de virtualidade. Trazer a crueldade à cena é também dispor um combate às fortalezas de um currículo que em nome de sua proteção das forças, o asfixia.

Se a crueldade refere-se ao modo como as forças tocam nas formas da vida, uma ética da crueldade curricular é antes e, sobretudo, um compromisso com a vida de um currículo, com a potência de uma vida. A crueldade em Artaud é isto que "exprime a lógica da vida, ou atribui a vida uma definição puramente lógica. Uma nova lógica que não obedece às leis da racionalidade moral, mas que se apresenta, justamente, como a lógica da ética" (DUMOULIÉ, 1996, p. 25). Uma lógica que funciona mais pelo seu grau de potência, o poder de um currículo afetar, sua força de contágio sobre a vida dos seres e povos que aí existem, em como um currículo contagia e se deixa contagiar. Uma ética da crueldade curricular é antes e, sobretudo, um compromisso com a vida de um currículo, com a potência de uma vida. A vida é potência e "o sentimento de potência é exatamente o equivalente a crueldade" (NIETZSCHE, 1986, p. 84). A questão da crueldade só tem relação com a categoria da ética e, inversamente, a questão da ética nos introduz a dimensão da crueldade para engravidar de virtualidades outras a atualidade cinzenta de um currículo e das formas de vida que ele constitui, abrir paisagens onde tudo parecia sufocado demais. E, se a ética concerne à textura e a qualidade de toda uma forma de vida, as exigências éticas são também coextensivas ao trabalho da cultura ${ }^{11}$, em que "pensa-se sempre contra a cultura, mas sempre sobre a cultura, na espera, se é possível, de uma cultura por vir" (PELLEJERO, 2008, p. 2).

Ainda que seja preciso reconhecer que, tradicionalmente, a ética tem sido discutida ora como algo que diz respeito ao bem ora como algo que compete ao direito, o que constitui um claro embate entre os arautos da virtude e da felicidade em oposição aos apologistas do direito e das obrigações morais. A própria determinação ética da pedagogia tem dado lugar ao juízo moral, submetendo os currículos à convenção do Bem e do Mal (CORAZZA, 2002). Porém, seja de que forma for, até agora "o que não se perguntou foi se pode haver algo de novo na ética?" (RAJCHMAN, 1993, p. 167). Se pudermos tomar a ética como "uma tipologia dos modos de existência imanentes, [...] a diferença qualitativa dos modos de existência" (DELEUZE, 2002, p. 28), estamos diante de um exercício que nos habilita a desfrutar as forças de uma vida, a reagir a ela de maneira mais sensível, a saborear a doçura e a violência do movimento das forças que rondam um currículo. A crueldade entra no território da ética, justamente "para acabar com o Julgamento de Deus" (ARTAUD, 1983, p. 43), 
para não submetê-la ao vampirismo moralizante do juízo teológico do Bem contra o Mal. "Pesar os nervos" (ARTAUD, 2004, p. 118) e por para pensar o imponderável na vida de um currículo.

Ética da crueldade cuja tradução encontra-se no Ecce Homo de Nietzsche (2007b, p. 138): "Eu prometo uma era trágica: a arte suprema do dizer Sim à vida. A tragédia renascerá quando a humanidade tiver atrás de si a consciência das mais duras, porém, necessárias guerras sem sofrer com isso". Essa libertinagem de ação da crueldade denega e suspende o real para ascendermos a uma paisagem inédita. "Uma paisagem que sente aproximar-se a tempestade [até] desembocar na explosão brusca de uma tempestade" (ARTAUD, 1964, p. 25). Uma crueldade "cuja amplidão sonda nossa vitalidade integral, nos coloca diante de todas as nossas possibilidades" (ARTAUD, 2006, p. 94) e que implanta em um currículo um apelo contra a eternização arbitrária de uma forma de vida. A questão, agora, está em saber se é possível conceber novos modos de ser que já não se apoiem na rigidez paralisante das formas.

Não se trata mais somente de descrever formas de vida. A questão insaciável agora talvez seja: porque essa forma de vida e não outra? Também pode ser: com que outras forças as formas de vida de um currículo podem entrar em relação? Que novas formas de vida podem daí surgir? Uma crueldade que também pode funcionar a favor da virtualização e potenciação da vida. Se ética é uma relação, com a crueldade somos levados a pensar a ética de um currículo como a relação de suas formas com as forças que as tocam, como o exercício cruel de invençâo das formas de vida em um currículo é levado a encontrar-se como a violência das forças para abrirem as formas que resistem a se desprenderem de onde estão: experimentar uma convivência caótica entre o que somos e o que podemos nos tornar. Fazemos, doravante, um esforço, ainda que incerto, para compor uma ética da crueldade da curricular com Antonin Artaud.

I. Imagem do fogo: Fazer de um currículo manifestação inesquecível como "conflito perpétuo onde a vida se dilacera a cada minuto", onde tudo na sua criação "[...] se ergue contra nosso estado de seres constituídos" (ARTAUD, 2006, p. 105), faz arder nossa memória de humanos. A imagem do fogo passa da crítica à experimentação, num movimento paralelo e simultâneo, que nos leva da "genealogia do currículo" (TADEU; CORAZZA, 2003) à destruição da sua atualidade como um sinal das possibilidades latentes onde nada se deixa prever. Um currículo que ao constituir formas de vida também ataca o próprio exercício de constituição. Sua imagem de pensamento é, agora, o fogo - "[...] 
projeção perfeita e símbolo da vontade irritada/ e que se rebela imagem única da rebeliăo,/ o fogo separa e se separa/ ele mesmo une e desune/o que ele queima é ele mesmo" (ARTAUD, 1971, p. 121). Um princípio de fecundação da vida, para o qual o exercício de criação do fogo passa pela incineraçâo de si mesmo, "queimar o lugar, levantar outro ideal noutro lugar, uma vontade completamente diferente" (DELEUZE, 1976, p. 81). Não significa uma aniquilação, um vale-tudo ou abandono total de todas as visôes ou mesmo das teorias de currículo. Ao contrário, o fogo as requisita, escolhendo e acolhendoas para queimá-las, abri-las ao imprevisto, ao náo pensado imposto pela violência das próprias forças de um currículo. $\mathrm{E}$ ao queimar o que se encontra visivelmente petrificado, afeta todas as categorias do pensamento quando estas são formuladas sobre um horizonte essencialista. Contraposto ao simbólico, à síntese, à reunião, à unificação, negando qualquer possibilidade de repouso, de acordo ou de institucionalizaçáo, o furor incendiário da crueldade faz de um currículo multiplicidade sem unidade, afirmação da vida que produz a si mesma como diferença.

II. Estética do salto: Submeter um currículo ao movimento incessante de uma criação contínua que não admite sucesso ou fim. Usar a si a mesmo para desestabilizar os modelos tradicionais, as marcas notáveis, o tempo da ordem, da estabilidade e da precisão com os quais um currículo sempre esteve tão fortemente envolvido. Currículo sem freios, nem guias, nem limites, corredor alado! Não foi este, certa vez, um dos sentidos do vocábulo currículo (GOODSON, 1995; PINAR, 2004)? O território homogêneo e fechado de um currículo cede pouco a pouco lugar a um espaço incerto, na indeterminação das linhas da paisagem construída por tudo que lhe convém. Quantas paisagens não são construídas por meio de encontros com um elemento qualquer em um currículo? Quantas de nossas formas de vida, essas que nós nem sequer notamos, náo encontram em um currículo algo que leva a abertura de uma paisagem inédita no território cercado de um currículo? De uma história imprevista? De uma experiência notável? Um material qualquer, que às vezes nem na programaçáo estava, mas amplia o território de um currículo e estabelece conexóes. Um elemento, um livro ou uma letra, uma imagem ou um objeto como os quais se podem descobrir novas relaçóes de força, reconstituir modos inexplorados de existência, capazes de colocar-nos à altura, de fazer-nos dignos de conceitos e valores diferentes (DELEUZE, 1998). Isso não significa mudar simplesmente a forma dos currículos. "Formas não podem se movimentar, 
no máximo lhes é concedido preparar o movimento" (DELEUZE, 1988, p. 88). Inter, trans, por conteúdos, temáticas, temas geradores, ciclos, as matérias típicas de um currículo ainda permanecem imóveis: a Humanidade, a Moral, $\mathrm{O}$ Bem, O Mal. Há de se por elas em transformaçáo para passarem de uma forma a outra, fazê-las pular. Uma estética do salto que póe os métodos de um currículo a estranhar a si mesmo em seu próprio exercício de existência. Nem sequer precisamos recusar nenhuma dessas "matérias", peguemo-las e as usemos contra si mesmas. Essas matérias são algo que se apresentam em um currículo para serem simplesmente usufruídas, são territórios problemáticos e que se valem da crueldade para existir. Uma ética da crueldade curricular que nasce da convicção de que os valores e os conceitos não são os mesmos para todos, que a dialética do universal e do individual não ajuda ninguém, e a ninguém dá voz. Existe algo de potente em nossos currículos, algo infinitamente pequeno e estranho que brota ali; sem nenhuma possibilidade de totalização, só nos cabe deixá-los crescer e brotar.

III. Pedagogia do combate: Implantar em um currículo a "necessidade de agir diretamente e profundamente sobre a sensibilidade" (ARTAUD, 2006, p. 109), para fazer dele algo de uma ordem que "nos desperte nervos e coração" (ARTAUD, 2006, p. 95). Uma pedagogia do combate que age por uma violência às sensibilidades para tirar as formas de vida do entorpecimento ineficaz que os currículos tal como estão aí colocam. Com suas flechas envenenadas, essa pedagogia age nos levando a vagar por caminhos de um currículo, construindo rotas imprevistas, escapando a rigidez dos hábitos e da língua das estradas curriculares. Coloca as formas de vida em ação no mundo, numa busca incessante por plasticidade para ocupar o espaço de múltiplos modos e permitir que a violência da crueldade as redirecione a outros possíveis. Quando um currículo é algo da arte de superfícies de inscrição da vida, o que importa a esse exercício de ética da crueldade curricular é que "a sensibilidade seja colocada num estado de percepção mais aprofundada e mais apurada" (ARTAUD, 2006, p. 104). Querer fazer de um currículo algo "contenha para o coração esta espécie de picada concreta que comporta toda a sensaçáo verdadeira" (ARTAUD, 2006, p. 97). Uma plasticidade venenosa através da qual um terrorismo perverso as formas sensíveis da vida, por meio de experiências particulares, "experiências farmacodinâmicas, ou experiências físicas como as da vertigem" (DELEUZE, 2000, p. 384), "ensina" a singularidade da criaçáo, a coincidência do próprio movimento criativo da vida com a crueldade e faz a crueldade chegar aos 
espíritos. As formas de vida de um currículo só se mantêm atentas às forças que rondam os mundos de um currículo quando são mantidas sensíveis a elas, quando são violentadas pelas forças no campo de batalha da cultura. Um currículo que invade o mundo dos mortos-vivos das formas, dos zombies da vida, acordando-os pelo apetite pelo não-ser, pela não-forma, pelo informe e faz a vida transitar na experiência limite entre aquilo que é uma forma de vida e aquilo que ela pode tornar-se, em proveito das forças que sob ela se agitam.

IV. Lógica do sensível: isso não quer dizer deixar ao sabor absoluto das sensibilidades. Primeiro, porque é necessário precisar que a pedagogia dos sentidos da ética da crueldade não é um "gênero" ou um "tipo" particular de pedagogia que ergue seu tipo próprio de currículo com uma ética que lhe seja correspondente. Qualquer currículo, em sua ambição por taxonomias ontológicas, teve que apresentar uma educação dos sentidos. Certamente envolvida com a experiência promovida pelos usos dos sentidos humanos, mas, sobretudo, com as tentativas de construção de subjetividades e de políticas de conhecimento que enfatizam, utilizam e valorizam a experiência sensível como parte constituinte. Segundo, desse modo, os sentidos também se educam, se forjam e se tangem, são contingenciados por regimes históricos e dinâmicas culturais (GAY, 2001). As funçôes sociais bem conhecidas de um currículo arriscaram uma mutilaçâo dos sentidos, seja por seu disciplinamento biopolítico como formação do homem moderno (CARUSO, 2005), seja por sua explosão/ exploração espetacular empresarial no mundo contemporâneo (TURCKE, 2010). Contudo, ainda que se pareça tornar vã toda ética da crueldade, um currículo tem tantas variaçóes e expressóes, tantos modos de acontecer, que não se conseguirá captar a crueldade do desvio, do deslizamento, do deslocamento das forças da vida, aquela violência das máquinas produtoras de práticas de pensamento criadoras.

Com efeito, a crueldade nos leva a pensar com os sentidos, "não recear ir táo longe quanto necessário à exploraçáo de nossa sensibilidade nervosa" (ARTAUD, 2006, p. 98). Essa pedagogia do combate precisa mesmo de um outro "sentido intelectual determinado" (ARTAUD, 2006, p. 98). Uma lógica própria do sentido capaz de reverter a metafísica das nossas formas de vida (DELEUZE, 2000), apta a se revoltar contra o homem psicológico e as políticas de recognição. Uma ética que pôe em xeque a territorialidade metafísica e transcendental das formas vida de um currículo. As formas de vida de um currículo são invençôes mundanas, não estão nem além nem aquém do nosso 
mundo. "No caminho que leva o que existe para ser pensado, tudo parte da sensibilidade" (DELEUZE, 1988, p. 239), ela é a gênese do pensamento e da criação das formas de vida. "Não se separa [...] os sentidos da inteligência, sobretudo em que a fadiga precisa ser incessantemente renovada para reanimar nosso entendimento" (ARTAUD, 2006, p. 98). Uma lógica do sensível que pensa com o sensível e póe o sensível para pensar. Torcer o foco de um currículo que póe o cérebro para pensar a favor de uma sensibilidade pensante. O que essa ética diz, é que ele, o cérebro, não é a imagem rosa-carmim ou azul-marinho que nos acostumamos nas tomografias computadorizadas, que não pertence a um homem! Ele, o cérebro, está no mundo, é sensibilidade do mundo! "É o cérebro que diz Eu, mas Eu é um outro" (DELEUZE; GUATTARI, 1997, p. 270).

V. Lugar do Outro: a crueldade origina-se, exatamente, no lugar do Outro, no lugar de uma alteridade absoluta, não porque promulgue uma forma de idealismo intersubjetivo, faça valer os direitos da razão comunicacional ou do consenso dialógico. Diante da atual retórica da diversidade que invade os currículos, uma retórica que não parece ser outra coisa que uma "pluralización de lo mismo, o una multiplicación repetitiva del yo" (SKLIAR, 2002, p. 91), a crueldade responde com uma exposição à natureza chocante de uma alteridade insuportável. Numa reação hiperbólica às nossas atuais políticas de reificação, a crueldade devolve um Outro inalcançável, inabordável, que irrompe a coerência e consenso como um bloco de forças heterogêneas e acontece de todas as formas. Um Outro que chega à casa curricular sem convite, estranho, exorbitante, incondicional, não representável, escandaloso, incomensurável, que age nas bordas dos nervos. Assusta as sensibilidades não porque é sujeito ou objeto de uma nova proposta curricular com a qual não sabemos lidar, nem mesmo porque faz valer uma relaçáo tranquila, transparente, consistente, incondicional ou empática. Antes, um Outro que é uma virtualidade de um mundo assustador, que tem uma realidade própria em si mesmo, enquanto virtual (DELEUZE, 2000). Náo poderia ser um currículo um espaço onde já náo vale exclusivamente mais o nome que se leva, nem o lugar de onde se vem, mas a multiplicidade da existência que pode ser composta com os nomes do mundo que se encontram em seu espaço? A crueldade perturba o saber, o conhecimento, a verdade ou intencionalidade que materializam as formas de vida em um currículo para que difiram de si mesmas. A travessia entre os territórios da vida náo pode ser encerrada, mesmo em nome da paz, é preciso mantê-la viva, pulsante e aberta. Por mais que um currículo tente fechar formas, conteúdos, significados, saberes 
e verdades, identidades, sujeitos e subjetividades, a crueldade curricular nos póe em contato com o Outro como multiplicidade das almas ou dos mundos contidos em cada uma delas e as desenvolve em um sentido radical.

VI. Economia do divino: começar a "extrair uma ideia da cultura, uma idéia que é antes de tudo um protesto" (ARTAUD, 2006, p. 107). Contra a degenerescência da vida: "ela quer saber por que a vida está doente, e o que faz apodrecer a idéia de vida" (ARTAUD, 2006, p. 105). Tratar a vida não somente como forma, mas e, sobretudo, como força. "Se falta enxofre a nossa vida [...], é porque nos apraz contemplar nossos atos e nos perder em consideraçóes sobre as formas sonhadas de nossos atos, em vez de sermos impulsionados por eles" (ARTAUD, 2006, p. 8). Uma cultura que jamais pesa, porque náo concede as formas compostas da vida, impulsiona um currículo a ceder às forças componentes. O impressionante, agora, é que a vida seja de tal forma e não de outra, pois uma forma de vida náo pode ser descrita nem pela biologia nem mesmo pelas condiçôes sociais nas quais se vive. Exercício de construir uma cultura que só pode atestar entre as coisas "uma idéia mágica e violentamente interessada" (ARTAUD, 2006, p. 6) que deixa de representar a força que enclausura as formas e aparece como uma aventura pelas forças, que encadeia uma sensibilidade e, logo, um pensamento com todas as violências e crueldades necessárias para fazer das formas um traço da criação da vida. Tudo isso para a cultura "se tornar em nós como um novo órgáo" (ARTAUD, 2006, p. 6). Espécie de infinitas pelas tatuadas tanto pela agulha que penetra como pelo suor que escorre de sua superfície. Faz deste líquido quente e salgado a tinta que incendeia o mundo, agitadora "das sombras nas quais a vida nunca se deixou fremir" (ARTAUD, 2006, p. 7). O currículo torna-se meio e produto de uma cultura "baseada sobre o espírito em relação com seus órgãos, e o espírito banhando todos os órgãos e respondendo a si mesmo simultaneamente" (ARTAUD, 1967, p. 201). A crueldade de um currículo, agora, fere o corpo, rasga o peito, rompe a naturalidade dos dias, em "uma cultura da afirmaçáo, aberta à criação do novo, onde a vida, e a acção, e a liberdade, voltem a ter mais importância que a conservação e a reprodução do instituído" (PELLEJERO, 2008, p. 9). Extrai das formas, forças que sejam estimulantes à própria vida e, pelas quais, se extraia da vida a força da motivação que nos leva a acreditar no que nos faz viver.

VII. Exigência da crise: um currículo e a cultura não podem andar juntos, contrariamente ao uso que se fez universalmente deles. Um currículo torna-se 
um ato de devoração das formas da cultura, esta aí para fazer passar algo que escape os códigos: fluxos e linhas de fuga, "linhas de descodificação absoluta que se opóem à cultura” (DELEUZE; 2002, p. 36). Uma ética da crueldade curricular passa por uma exigência da crise permanente das formas de vida da cultura, pois é "justo que de tempos em tempos se produzam cataclismos que nos incitem a reencontrar a vida" (ARTAUD, 2006, p. 7), que nos apartem das convicçôes e até mesmo das incertezas trazidas pela observação e reconhecimento das formas de vida. "Acordar as forças que dormem em todas as formas e que não podem surgir de uma contemplação das formas, mas de uma identificação mágica com essas formas" (ARTAUD, 2006, p.8). Em sua abertura a esse mundo pululante das singularidades anônimas e nômades, impessoais e pré-individuais que é a cultura enquanto berço da magia e do sonho, um currículo atualiza novas maneiras de acontecer no mundo. Seu pensamento se propóe a construçáo de formas potentes sobre o plano de expressão da vida, mesmo que à custa das maiores forças e cruéis movimentos de desmontagem dos códigos da cultura. A qualidade de um currículo se mede agora por sua capacidade de enriquecer as forças ativas dos humanos, tais como "forças de recordar, de conceber, de querer" (DELEUZE, 1988, p. 132), "a força de viver, a força de falar, a força de trabalhar" (DELEUZE, 1988, p. 140). Tornar infinitas as fronteiras do que ousamos chamar de realidade e de humanidade.

Chegamos a um currículo com a fórmula do Teatro da Crueldade: "Vidamanifestação: Teatro-manifestação e Crueldade-rigor, pois intensidade, pois presença de Vida” (ARTAUD, 1978, p. 279). Esta pode ser a posição ética para um currículo. Um movimento capaz de enfrentar as forças violentas da vida e desalinhar suas formas estatutárias da vida. Esta "Revoluçáo se expande por toda a parte, é uma Revolução pela cultura e na cultura” (ARTAUD, 1964, p. 278). Entregar a vida de um currículo ao seu sentido dinâmico e virulento, ao charme sutil e sublime da crueldade, à arte de refazer a vida. Embora venha prenha de uma ambiguidade terrível de destruir e autodestruir, a ética da crueldade de um currículo, é tanto uma vontade de forma, de adestramento, como também uma vontade de afirmação, de construção, de criação e expansão da vida. $\mathrm{O}$ que precisamos, agora, talvez seja deslocarmos nosso foco para este outro lado da balança, para linha pela qual a crueldade torna-se mobilização da vida. Isto é, para o imperativo ético das forças que só mobilizam a vida de um currículo e as formas de vida que ele sustenta por um exercício de crueldade. Porque a ambivalência da crueldade em suas distintas matizes de inscrição na cultura, não 
é, para um currículo, um paradoxo que lhe dá um princípio de funcionamento, sem ser ao mesmo tempo um movimento de forças que perpetua o movimento de invenção da vida.

\section{Notas}

${ }^{1}$ Sem pretendermos sermos esgotantes, conferir, a título de exemplo, sobre literatura e crueldade, Georges Bataille (1981); sobre cinema e crueldade, Olivier Mongin (1999); sobre a crueldade e a fotografia, Susan Sontag (2003) e sobre mídia e a crueldade, a coletânea Estética da crueldade organizada por Ângela Dias e Paula Glenadel (2004).

${ }^{2}$ Ainda que a crueldade tenha entrado no pensamento filosófico desde Aristóteles em Ética a Nicômaco, certamente deve-se a época moderna sua retomada. Aqui, sem pretendermos ser esgotantes, ela encontra expressão filosófica nos conselhos de Maquiavel, nos ensaios de Montaigne, na filosofia política de Hobbes, no existencialismo de Schopenhauer, na crítica ao capitalismo de Marx e na sua forma mais radical na filosofia de Friedrich Nietzsche. Hoje, seria possível somar a essa lista, deveras incompleta e resumida, as formulaçóes de Michel Foucault, Gilles Deleuze, Jacques Derrida e Giorgio Agambem. Sem contar os debates teorizados em torna da Escola de Frankfurt, especialmente as teses de Hanna Arendt e Theodor Adorno. Um mapeamento da crueldade na filosofia ainda estar por se fazer.

${ }^{3}$ Clement Rosset (2002) intenta propor certo número de princípios que regeriam uma ética da crueldade: o princípio da realidade suficiente e o princípio da incerteza que teriam por objeto fazer aparecer a crueldade do real. Essa noçáo de real é, contudo, como sugerimos, muita mais problemática em Artaud do que Rosset faz parecer.

${ }^{4}$ É possível reconhecer, mesmo que em um breve passeio, que Michel Foucault, Gilles Deleuze, Félix Guattari, Jacques Derrida foram leitores dedicados de Antonin Artaud. Para destacar apenas os ensaios mais conhecidos: Jacques Derrida (1971, 1998), em O Teatro da Crueldade e o Fechamento da Representação, A palavra Soprada e Enlouquecer o subjéctil; Gilles Deleuze (2000), em Lógica do Sentido, Gilles Deleuze e Félix 
Guattari (2004, 1997), em o Anti-Édipo e Mil Platôs, respectivamente. Poderia acrescentar o ensaio de Maurice Blanchot (2005), em O livro por vir, e a notável referência de Michel Foucault (1998) ao final de $A s$ palavras e as coisas.

${ }^{5}$ É possível referir ainda que de modo bastante limitado e superficial as três Cartas sobre a Crueldade inseridas em O Teatro e Seu Duplo, ao Manifesto do Teatro Alfred Jarry, a última das três Cartas sobre a linguagem ou ainda a página capital de Acabar com as Obras-Primas.

${ }^{6}$ Este paradigma, chamado por Stuart Hall (2002) de "culturalista", estaria exemplificado nos trabalhos de Raymond Williams, Richard Hoggart e Edward Thompson, assumindo, certamente, heterogeneidades e sutilezas entre seus trabalhos. A própria marca "culturalista" advém dos trabalhos de Richard Johnson e nunca foi usada por Williams, Hoggart ou Thompson para designarem suas produçóes. Porém, mesmo permitindo aos Estudos Culturais se assentarem e oferecendo o tecido no qual as teorizaçóes posteriores trabalharam, a questáo da "cultura como modo de vida" teria declinado, continua a sugerir Hall (2002), em função de uma suposta ingenuidade diante da crítica da economia política de inspiração estruturalista, a ponta de permitir a formulação de cultura como práticas de significação. No entanto, ainda que se possa assumir entre essas formulaçôes um desnível, Hall (2002) alerta que nâo se pode falar na constituição de dois paradigmas do conceito de cultura reguladores dos Estudos Culturais. Este artigo acompanha a sugestáo de Seigworth (2006), para quem os conceitos revigorados de experiência e empirismo apresentados por Gilles Deleuze vêm potencializar tanto uma retomada das formas de vida como cultura quanto se soma as práticas de significação sem que precise constituir um novo conceito ou paradigma.

${ }^{7}$ Os Estudos Culturais surgem na década de 1960 como prática institucionalizada a partir de pesquisas do Center for Contemporary Cultural Studies sediado na Escola de Birmingham, na Inglaterra. Sua realização mais importante talvez seja a de celebrar o fim de um elitismo edificado sobre as distinçôes arbitrárias da cultura. Para uma introdução, consultar Matterlat e Nevau (2004). 
${ }^{8}$ Para uma ampla caracterização desse movimento, ver Jameson (1996), Hall (1997) e Canclini (1998). Para a centralidade dessa discussáo no campo da educação e do currículo, destacamos os trabalhos de VeigaNeto (2003), Paraíso (2004); Macedo (2006a; 2006b) e Silva (2006).

${ }^{9}$ A discussão sobre cultura pode ser tomado, hoje, como a principal tendência do campo curricular (LOPES; MACEDO, 2002, 2006). Contudo, o conceito de cultura não é trazido ao campo pelos Estudos Culturais, embora eles façam uma profunda reviravolta na discussão vigente. As teorizaçôes tradicionais e críticas, a partir da Sociologia do Currículo Americana e da Nova Sociologia da Educação já tinham posto o par currículo e cultura em discussão no campo curricular (MOREIRA, 2002). As interfaces entre cultura e currículo se tornam, então, progressivamente preocupaçóes centrais dos trabalhos de autores como Henry Giroux e Peter McLaren, por exemplo, e no Brasil, dos trabalhos de Antonio Flavio Moreira e Tomaz Tadeu da Silva. Moreira e Silva (2008) chegaram a destacar como tema central da análise crítica e sociológica de currículo a ideologia, a cultura e o poder. Somam-se, aqui, ainda as linhas do multiculturalismo de influência norte-americana nos trabalhos do próprio Antonio Flávio Moreira e de Ana Canen. No entanto, Silva (2006) destacou que as teorizaçóes crítica do campo curricular têm operado com um conceito fundamentalmente estático e essencialista de cultura e Macedo (2006b) alertou para o fato de que o conceito de cultura continua a soar, em sua maioria, como um conjunto de repertórios dados em um campo social.

${ }^{9}$ Gilles Deleuze (1976), largamente inspirado na obra de Friedrich Nietzsche, estabelece uma tipologia das forças, distinguindo entre forças reativas e forças ativas. As primeiras exercem-se assegurando os mecanismos e as finalidades, preenchendo as condiçóes de vida e as funções, as tarefas de conservação, de adaptação e utilidade. As segundas não concedem à utilidade e à conversação, exerce-se se apoderando, impondo-se, criando formas, explorando circunstâncias, são as forças plásticas da metamorfose.

${ }^{10} \mathrm{O}$ próprio exercício do Teatro da Crueldade, como ressaltado por Artaud nas três cartas sobre a crueldade inseridas na sua mais conhecida obra O Teatro e seu duplo, é um exercício que se faz na e pela cultura. Dela se 
extrai os elementos para compor uma cena contra a cultura, como se o teatro substituísse a história da cultura por um teatro da cultura exposta aos seus próprios fantasmas.

${ }^{11}$ Estamos nos referindo tanto aqueles que aprendemos a chamar de olfato, visão, paladar, audiçáo e tato e a identificar seu adestramento, como ao próprio processo civilizatório racional moderno, regulado ou planejado das sensaçóes dos quais as escolas e os currículos foram dispositivos privilegiados de sua execução.

\section{REFERÊNCIAS}

AGAMBEM, Giorgio. Means Without End: Notes on Politics. Minneapolis: Univ. of Minnesota Press, 2000.

ALMEIDA, Ricardo. A vontade de crueldade nos escritos trágicos de Nietzsche. Filosofia Unisinos, São Leopoldo, RS, n. 9, v. 2, p. 120-134, maio/ago 2008.

ALVES, Karina. Formação discursiva da plenitude em educação: uma arqueogenealogia das novas sensibilidades eco-pedagógicas. 2009. Tese (Doutorado em Educação) - Universidade Federal de Pernambuco, Recife, 2009.

ARTAUD, Antonin. Oueuvres complètes. Paris: Gallimard, 1964. Tomo 5.

ARTAUD, Antonin. Oueuvres complètes. Paris: Gallimard, 1967. Tomo 7.

ARTAUD, Antonin. Oueuvres complètes. Paris: Gallimard, 1971. Tomo 8.

ARTAUD, Antonin. Oueuvres complètes. Paris: Gallimard, 1974. Tomo 10.

ARTAUD, Antonin. Oueuvres complètes. Paris: Gallimard, 1976. Tomo 1. v. 2.

ARTAUD, Antonin. Oueuvres complètes. Paris: Gallimard, 1978. Tomo 4.

ARTAUD, Antonin. Oueuvres complètes. Paris: Gallimard, 1979. Tomo 9.

ARTAUD, Antonin. Cartas desde Rodez 3. Madrid: Gallimard, 1977.

ARTAUD, Antonin. Acabar com as obras-primas. In: WILLER, C. (Org.). Escritos de Antonin Artaud. Porto Alegre: L\&PM, 1983. p. 15-19.

ARTAUD, Antonin. A arte e a morte. Lisboa: Hiena Editora, 1993.

ARTAUD, Antonin. O pesa-nervos. In: GUINSBURG, Jacó; FERNANDES, Silvia. (Org.). Linguagem e Vida. São Paulo: Perspectiva, 2004. p. 121-124. 
ARTAUD, Antonin. O Teatro e Seu Duplo. São Paulo: Martins Fontes, 2006.

BATAILLE, Georges. La literatura y el mal: Emily Bronte, Baudelaire, Michelet, Blake, Sade, Proust, Kafka, Genet. Madrid: Taurus, 1981.

BLANCHOT, Maurice. Conversa infinita: a palavra plural. São Paulo: Martin Claret, 2001.

BLANCHOT, Maurice. O livro por vir. São Paulo: Martins Fontes, 2005.

BUTLER, Judith. Fundamentos contingentes: o feminismo e a questão do "pós-moderno". Cadernos Pagu, Campinas, SP, v. 11, p. 11-43, 1998.

CANCLINI, Nestor Garcia. Culturas hibridas. São Paulo: EDUSP, 1998.

CARVALHAR, Danielle. Relaçóes de gênero no currículo da educação infantil: identidades de princesas, príncipes e sapos. 170f. 2009. Dissertação (Mestrado em Educação) - Universidade Federal de Minas Gerais, Belo Horizonte, 2009.

CARUSO, Marcelo. La biopolitica en las aulas: prácticas de conducción em las escuelas elementares del Reino de Baviera, Alemanha (1869-1919). Buenos Aires: Prometeo Libros, 2005.

CORAZZA, Sandra. Para uma filosofia do inferno na educação: Nietzsche, Deleuze e outros malditos afins. Belo Horizonte: Autêntica, 2002.

CORAZZA, Sandra. Pedagogia dos sentidos: a infância informe no método Valéry-Deleuze. In: KOHAN, Walter. (org). Devir-criança da filosofia: infância da educação. Belo Horizonte: Autêntica, 2010. p. 81-94.

CUNHA, Marlécio Maknamara da Silva. Currículo, gênero e nordestinidade: o que ensina o forró eletrônico? 2011. Tese (Doutorado em Educação) Universidade Federal de Minas Gerais, Belo Horizonte, 2011.

DALE, Catherine. Cruel: Antonin Artaud e Gilles Deleuze. In: MASSUMI, Brain (Org.). A shock of thought. Londres: Routledge, 2002. p. 85-100.

DIAS, Ângela; GLENADEL, Paula (Org.). Estéticas da crueldade. Rio de Janeiro: Atlântica, 2004.

DELEUZE. Gilles. Nietzsche e a Filosofia. Rio de Janeiro: Rio, 1976.

DELEUZE. Gilles. Foucault. São Paulo: Brasiliense, 1988.

DELEUZE. Gilles. A dobra: Leibniz e o barroco. São Paulo: Papirus, 1991. 
DELEUZE. Gilles. Proust e os signos. Rio de Janeiro: Forense Universitária, 1998.

DELEUZE. Gilles. Lógica do Sentido. Rio de Janeiro: Jorge Zahar, 2000.

DELEUZE. Gilles. Espinosa: filosofia da prática. São Paulo: Escuta, 2002.

DELEUZE. Gilles. Sacher-Masoch: o frio e o cruel. Rio de Janeiro: Jorge Zahar, 2008.

DELEUZE, Gilles; GUATTARI, Félix. Mil Platôs: capitalismo e esquizofrenia. Rio de Janeiro: 34, 1997. v.3.

DELEUZE, Gilles; GUATTARI, Félix. $O$ anti-édipo: capitalismo e esquizofrenia. Lisboa: Assrio \& Alvim, 2004.

DERRIDA, Jacques. A escritura e a diferença. São Paulo: Perspectiva, 1971.

DERRIDA, Jacques. Enlouqueçer o subjéctil. São Paulo: Ateliê Editorial, 1998.

DUMOULIÉ, Camillé. Nietzsche y Artaud: por una ética de la crueldad. Cidade do México: Siglo XXI, 1996.

FOUCAULT, Michel. As palavras e as coisas. São Paulo: Martins Fontes, 1998.

FOUCAULT, Michel. Vigiar e punir. Petrópolis, RJ: Vozes, 1999.

FREITAS, Daniela da Silva. O discurso da educação escolar nas HQs do Chico Bento. 2008 Dissertação (Mestrado em Educação) - Universidade Federal de Minas Gerais, Belo Horizonte, 2008.

GALENO, Alex. Antonin Artaud: a revolta de um anjo terrível. Porto Alegre: Sulina, 2005.

GAY, Peter. Educação dos sentidos. São Paulo: Companhia das letras, 2001.

GOODSON, Ivor. Currículo: teoria e história. Petrópolis: Vozes, 1995.

HALL, Stuart. Da diáspora: identidades e mediaçōes culturais. Belo Horizonte: Editora da UFMG, 2002.

HALL, Stuart. A centralidade da cultura: notas sobre as revoluçóes culturais do nosso tempo. Educação \& Realidade, Porto Alegre, RS, v. 22, n. 2, p. 1546, jul./dez 1997.

HEGEL, Goerge. Curso de estética. São Paulo: EdUSP, 2004. v.5. 
HOBSBAWN, Eric. A era dos extremos. São Paulo. Companhia das Letras, 1995.

JAMESON, Friedrich. Pós-modernismo: a lógica cultural do capitalismo tardio. São Paulo: Ática, 1996.

JOHNSON, Richard. O que é, afinal, Estudos Culturais? In: SILVA, Tomaz Tadeu da. (Org.). O que é, afinal, Estudos Culturais? Belo Horizonte: Autêntica, 2006. p. 7-131.

LINS, Daniel. A história da cultura é a história da crueldade. In: FEITOSA, Charles. et al. (Org.). Assim falou Nietzsche. Rio de Janeiro: DP\&A, 2003. p. 305-320.

LOPES, Alice Casimiro; MACEDO, Elizabeth. O pensamento curricular no Brasil. In: LOPES, Alice; MACEDO, Elizabeth (Org). Currículo: debates contemporâneos. São Paulo: Cortez, 2002. p. 13-54.

LOPES, Alice Casimiro; MACEDO, Elizabeth. Currículo da Educação Básica (1992- 2002). Brasília: Ministério da Educação, 2006.

LUENGO, Fabíola. A vigilância punitiva: a postura dos educadores no processo de patologização e medicalização da infância. São Paulo: Cultura Acadêmica, 2010.

MACEDO, Elizabeth. Currículo como espaço-tempo de fronteira cultural. Revista Brasileira de Educação, Rio de Janeiro, v. 11, n. 32, p. 285-296, maio/ago 2006 a.

MACEDO, Elizabeth. Currículo: política, cultura e poder. Currículo sem fronteiras, Pelotas, RS, v. 6, n. 2, p. 98-113, jul/dez, 2006 b.

MAFFESOLI, Michel.A violência totalitária: ensaio de antropologia política. Rio de Janeiro: Zahar, 1981.

MATTELART, Armand; NEVEU, Éric. Introdução aos Estudos Culturais. São Paulo: Parábola, 2004.

MONGIN, Oliver. Violencia y cine contemporâneo. Barcelona: Paidós, 1999.

MOREIRA, Antonio Flávio Barbosa. Currículo, diferença cultural e diálogo. Educação e Sociedade, Campinas, SP, v. 23, n. 79, p. 15-38, ago. 2002.

MOREIRA, Antonio Flávio; SILVA, Tomaz Tadeu. Sociologia e teoria crítica do currículo: uma introdução. In: MOREIRA, Antonio Flávio; SILVA, Tomaz Tadeu (Org.). Currículo, Cultura e Sociedade. São Paulo: Cortez, 2008. p. 7-37. 
NIETZSCHE, Friedrich. Obras incompletas. São Paulo: Abril, 1983.

NIETZSCHE, Friedrich. A vontade de potência. São Paulo: Escala, 1986.

NIETZSCHE, Friedrich. Assim falava Zaratrusta. São Paulo: Escala, 2006.

NIETZSCHE, Friedrich. Nascimento da tragédia. São Paulo: Companhia das Letras, 2007a.

NIETZSCHE, Friedrich. Ecce homo. São Paulo: Cia das Letras, 2007b.

NIETZSCHE, Friedrich. Genealogia da moral. São Paulo: Companhia das Letras, 2009.

PARAÍSO, Marlucy Alves. Raciocínios generificados no currículo escolar e possibilidades de aprender. In: COLÓQUIO SOBRE QUESTÓES CURRICUlares, 9., 2010, Porto. Anais... Porto: Universidade do Porto, 2010a.

PARAÍSO, Marlucy Alves. O currículo entre a busca por bom desempenho e a garantia da diferença. In: SANTOS, Lucíola L. C. P. (Org.). Convergências e tensóes no campo da formação e do trabalho docente. Belo Horizonte: Autêntica, 2010b. p. 132-152.

PARAÍSO, Marlucy Alves. É possível um currículo fazer desejar? In: PARAÍSO, Marlucy. (Org.). Pesquisas sobre curriculos e culturas. Curitiba: CRV, 2010c. p. 153-168.

PELLEJERO, Eduardo. A idéia de cultura na filosofia de Gilles Deleuze. Diacritica, Braga, n. 12, p. 1-19, 2008.

PINAR, William. I am a man: the queer politics of race. Cultural studies: critical methodologies, Thousand Oaks, CA, v. 2, n. 1, p. 113-130, 2002.

PINAR, William. What is curriculum theory? Mahwah: Laurence Erlbaum, 2004.

RAJCHMAN, John. Eros e Verdade: Lacan, Foucault e a questão da ética. Rio de Janeiro: Jorge Zahar, 1993.

REIS, Cristina D'ávila. Currículo escolar e gênero: a constituição generificada de corpos e posiçóes de sujeito meninos-alunos. 2010. Dissertação (Mestrado em Educação) - Universidade Federal de Minas Gerais. Belo Horizonte, 2010. 
REY, Jean. O nascimento da poesia. Belo Horizonte: Autêntica, 2002.

ROSSET, Clement. O princípio de crueldade. Rio de Janeiro: Rocco, 2002.

SALES, Shirlei Resende. Orkut.com.escol@: currículos e ciborguização juvenil. 2010. Tese (Doutorado em Educação) - Universidade Federal de Minas Gerais. Belo Horizonte, 2010.

SEIGWORTH, Gregory. Cultural Studies and Gilles Deleuze. In: HALL, Gary; BIRCHALL, Claire (Org.). New Cultural Studies. Athens: University of Georgia Press, 2006. p. 107-127.

SILVA, Maria Carolina. A infância no currículo dos filmes de animação infantil: poder, governo e subjetivação dos/as infantis. 2010. Dissertação (Mestrado em Educação) - Universidade Federal de Minas Gerais. Belo Horizonte, 2010.

SILVA, Tomaz Tadeu. O Currículo como fetiche: a poética e a política do texto curricular. Belo Horizonte: Autêntica, 2006.

SKLIAR, Carlos. Alteridades e pedagogias: ¿Y si el outro no estuviera ahí? Educação \& Sociedade. Campinas, SP, n.79, v. 23, p. 85-123, ago. 2002.

SONTAG, Susan. Diante da dor dos outros. São Paulo: Companhia das Letras, 2003.

TADEU, Tomaz; CORAZZA, Sandra. Composiçöes. Belo Horizonte: Autêntica, 2003.

TURCKE, Christoph. Sociedade excitada. Campinas, SP: Editora da Unicamp, 2010.

VIRMAUX, Alain. Artaud e o Teatro. São Paulo: Perspectiva, 1978.

WAGNER, Roy. A invenção da cultura. São Paulo: Cosac \& Naify, 2010.

WILLIAMS, Raymond. Cultura. Rio de Janeiro: Paz e Terra, 2008. 


\section{Curriculum, Culture And Cruelty: For A Composition Of Ethic With Antonin Artaud And The Theatre}

\section{Abstract}

This article seeks in the lines of force of Antonin Artaud's Theatre of Cruelty and in the Philosophy of Difference of Gilles Deleuze elements to compose an ethics of cruelty curriculum. So, this text develops the argument that the cruelty of life forms and cruel forces of life allow to feed the requirement of an ethics of the curriculum cruelty. Thus, it present the ethical and the cultural dimensions of the cruelty from the double forms/ forces put into play in the Theatre of Cruelty. It extracts, thus, an ethics of the cruelty curriculum that works from two movements: to give account of selfengendering of life forms in a curriculum and to think the fruitful movements that enable the ongoing invention of ways of living.

Keywords: Theories of curriculum. Cultural content of the curriculum. Philosophy of Education.
Curriculo, cultura e crueldad: por una composicion de ética con Antonin Artaud y el teatro

\section{Resumen}

Las referencias en este artículo se realizan a partir del "Teatro de la Crueldad" de Antonin Artaud y de la filosofía de la diferencia de Gilles Deleuze para componer una ética de la crueldad curricular. Argumentamos que la crueldad de las formas de vida y las fuerzas crueles de la vida permiten alimentar la necesidad de una ética de la crueldad curricular. Se propone, entonces, para explorar las dimensiones éticas y culturales de la crueldad como punto de partida la dupla forma/ fuerzas puesto en juego en el Teatro de la Crueldad. Así, extrae una ética de la crueldad curricular que funciona a partir de dos movimientos: dar cuenta del autoengendramiento de las formas de vida en un currículo y en los movimientos fructíferos que permiten a la invención constante de formas de vida.

Palabras claves: Teorías del currículo. Contenidos culturales del currículo.

Filosofía de la Educación. 
Thiago Ranniery Moreira de Oliveira

E-mail: t.ranniery@gmail.com

\section{Marlucy Alves Paraíso}

E-mail: marlucyparaiso@gmail.com

Recebido em: 12/4/2013

Versão final recebida em: 28/5/2013

Aprovado em: 30/5/2013 